\title{
CHARACTERIZATION OF CLAY MATERIALS USED FOR POTTERY PURPOSES FROM RENDENG, MALO, BOJONEGORO
}

\author{
Dyah Setyaningrum $^{1 *}$, Sujiat ${ }^{2}$, Aprilia Nur Azizah ${ }^{3}$ \\ ${ }^{1,3}$ Department of Chemistry, Science and Engineering of Faculty, University Bojonegoro \\ Jl. Lettu Suyitno No. 2 Bojonegoro 62119, East Java, Indonesia \\ ${ }^{2}$ Department of Civil Engineering, Science and Engineering of Faculty, University Bojonegoro \\ Jl. Lettu Suyitno No. 2 Bojonegoro 62119, East Java, Indonesia
}

Received: $29^{\text {th }}$ August 2021; Revised: $19^{\text {th }}$ November 2021; Accepted: $16^{\text {th }}$ December 2021

ABSTRACT

\begin{abstract}
Clay material from Rendeng, Malo, Bojonegoro was studied by mineralogy and physicochemical characterization to evaluate its potential suitability as a raw material in pottery application. X-ray Diffraction (XRD) and Fourier Transform-Infrared (FTIR) spectrometry were used to establish the mineralogy composition. Meanwhile the physical properties were identified by particle size distribution and consistency limits. Chemical composition was carried out by X-ray Fluorescence Spectrometer (XRF). The results of XRD characterization revealed that clay from Rendeng Village, Malo, Bojonegoro contained kaolin, quartz, and feldspar. Physical characterization shows that clay material is a less plastic type based on Atterberg method. Based on the chemical compositions indicated that $\mathrm{SiO}_{2}, \mathrm{Al}_{2} \mathrm{O}_{3}, \mathrm{CaO}$, and $\mathrm{Fe}_{2} \mathrm{O}_{3}$ were abundance oxides. Therefore, clay from Desa Rendeng was only suitable for the pottery purposes because most of its mineral compositions did not meet the quality requirements for making advanced ceramics.
\end{abstract}

Keywords: Clay material; Characterization; Kaolin; Pottery; Malo

\section{Introduction}

Clay minerals are the main constituent in the traditional ceramic industry as well as some advanced ceramic products. These minerals have plastic properties when mixed with a little water and will become very hard at high temperatures. ${ }^{1,2}$ They have varying chemical compositions depending on the environment where the clays are found.

In Indonesia, there are some regions recognized as the centers of the pottery craft. The production centers of pottery are Plered, Purwakarta; Kasongan, Yogyakarta; Dinoyo, Jawa Timur; and Pulutan, Minahasa, Sulawesi Utara. However, producing ceramics using traditional methods, which do not take to mineralogical and chemical characteristics, are still employed in these sector. Therefore, the quality control and also the characterization of clay minerals are prominent for local products. ${ }^{3,4}$ Limited

E-Mail: dyahds@gmail.com

research has been carried out on the potential use and quality of Indonesia clays in the pottery objects manufacture, such as. ${ }^{2,5}$

Malo is one of the sub-districts in the Bojonegoro Regency. This sub-district is famous for its pottery craft. One of the efforts to conserve it is to create Pottery Educational Tours (Wisata Edukasi Gerabah/WEG). This tour is centered at Rendeng Village, Malo Sub-district, Bojonegoro Regency. ${ }^{6}$

The main raw materials used by the pottery craftsmen come from a mountainous area. According to the craftsmen, the best clay is from subsoil lying on the edge of small hills. In spite of its high proportion, clay materials from this place are solely exploited for traditional pottery and local ceramic bricks.

Thus, this paper aims to contribute to the study of the mineralogical and physicochemical properties of Malo's clay 
materials. Besides, it can be used as information on the utilization of clay for other objects with a higher economic value.

\section{Methods}

The sample used in this study was clay from Rendeng Village. The clay was mash to powder form, then dried in the air dry, sieving, and beneficiated. Beneficiation was an activity to separate pure clay from its impurities. $^{7}$ By precipitating the clay into demineralized water with a ratio of $1: 2$ and letting it for 3 days, the beneficiated clay was then dried under the sun.

Then, oven-dried for another 24 hours at $105^{\circ} \mathrm{C}$ to remove water content. The strength of the soil is influenced by the water content, soil density, and soil grain gradation. ${ }^{8}$ The measurement of the water content was by subtracting the weight of the clay before it was dried by the weight of the clay after dried.

Subsequently, soil density was determined by referring to the standard of SNI 19642008. This testing was covered on the determination of specific gravity by using a pycnometer bottle. The tested soil must pass filter No. 40.

Plasticity index was based on the arithmetic difference in the water content of the liquid limit and the plastic limit. ${ }^{9}$ The plasticity index can be seen in Equation (1). The method for testing the plastic limit was by rolling a wet soil sample over the glass until exactly $3.2 \mathrm{~mm}$ of soil became cracked. ${ }^{9-10}$

$$
P I=L L-P L
$$

with $\quad P I=$ Plasticity Index

$$
\begin{aligned}
& \mathrm{LL}=\text { Liquid Limit } \\
& \mathrm{PL}=\text { Plastic Limits }
\end{aligned}
$$

The characterization the of chemical composition on the clay was conducted by using XRD and FTIR to determine the crystalline phase and mineral structure of the clay, respectively. ${ }^{1,11,12}$ An analysis of XRF was to find out the content and the concentration of each element in the clay. ${ }^{3,13}$ The testing was carried out at Advanced Mineral and Material Laboratory (Central Laboratory), Malang State University.

\section{Results and Discussion}

\section{Analysis of Physical Properties of Clay of Rendeng, Malo}

The analysis results of physical properties of clay of Rendeng, Malo include water content, specific gravity, and Atterberg Method presented in Table 1,

Table 1. The Testing Results of Soil Consistency Test using Atterberg Method and Sieve Analysis.

\begin{tabular}{clc}
\hline No & \multicolumn{1}{c}{ Testing } & Testing Result (\%) \\
\hline 1 & Water Content & 44.467 \\
2 & Specific Gravity & 2.15 \\
3 & \multicolumn{1}{c}{ Filter Analysis } & \\
& Pass the filter no. 10 & 100 \\
& Pass the filter no. 40 Atterberg Limits & \\
& Pass the filter no.200 & \\
4 & \multicolumn{2}{c}{45.4} \\
& Liquid Limit (LL) & 45.4 \\
& Plastic Limit (PL) & 32.4 \\
& Shrinkage Limit (SL) & 13.47 \\
& Plasticity Index (PI) & 13.0 \\
\hline
\end{tabular}

Table 1 shows that the sample of the clay of Bengawan Solo from Rendeng Village is included in the division of coarse-grained soil with $\geq 50 \%$ retained in the filter no. 200 . The retained grains and included in the sand are $65.4 \%$ with $\geq 50 \%$ of coarse fraction 
passing the filter no. 40 which is equal to 95.4\% of grain.

Plasticity is a technical parameter for the processing of clay-based materials. ${ }^{9}$ This parameter defines as an ability of a material that allows it to change shape without cracks or volume changes, depending on its water content. ${ }^{9}$ The liquid limit values of Rendeng, Malo clays at about $45.4 \%$ (Table 1). In the literature, the composition used for ceramic production is in the range $30 \%-60 \% .^{3}$

The analysis of the plasticity index of Bengawan Clay from Rendeng Village resulted in the value of 13 (based on equation 2). Based on the plasticity index according to
Atterberg, the clay of Rendeng Malo has medium plasticity and can be used as a raw material for making pottery/ ceramics. ${ }^{2,14}$

The chemical composition of the clay dust was tested by using an XRF instrument and showed the result as presented in Table 3 . From Table 3, it can be identified that the content of $\mathrm{SiO}_{2}$ and $\mathrm{Al}_{2} \mathrm{O}_{3}$ is the main component with the highest concentration in the sample. The domination of $\mathrm{SiO}_{2}$ and $\mathrm{Al}_{2} \mathrm{O}_{3}$ oxides is related to the existance of illite and kaolinite. According to ${ }^{1,12}$ if the ratio of both of them is around 1:3, this shows that there is quartz in the clay fraction.

Table 2. Characterization of XRF of Bengawan clay dust from Rendeng Village

\begin{tabular}{ccccccc}
\hline Compounds & $\mathrm{SiO}_{2}$ & $\mathrm{Al}_{2} \mathrm{O}_{3}$ & $\mathbf{F e O}$ & $\mathrm{K}_{\mathbf{2}} \mathrm{O}$ & $\mathbf{C a O}$ & $\mathrm{TiO}_{2}$ \\
\hline $\mathrm{Wt} \%$ & 63.3 & 20.9 & 4.8 & 1.59 & 5 & 0.96 \\
\hline
\end{tabular}

In addition, this oxide ratio can also give information related to material permeability moisture. The greater the unit weight, the greater is the permeability. Based on Table 2, the ratio around 0.3 confirms that the percentage of moisture is low. This was associated with the beneficiation process at the beginning of the treatment.

Based on the explanation from, ${ }^{12}$ the high $\mathrm{Ca}$ mineral in the material can influence chemical durability and chemical strength for ceramic products, especially for producing vase that must remain unaffected by fluctuations, temperature, and acidic substances. Also, the $\mathrm{FeO}$ mineral is very high, 4.8, where the value is far above the threshold for pottery raw materials, which is maximum 0.8 according to SNI 1145-1984.

Finding out mineral characterization and measurement in the form of complex crystals was done by using an XRD instrument. XRD patterns were recorded in PanAnalytical, type E'xpert Pro. Operating with $\mathrm{Cu} \mathrm{K \alpha}(0,15406$ $\mathrm{nm})$ radiation, generating at $40 \mathrm{kV}$ and 35 $\mathrm{mA}$. The diffractogram of the analysis result is presented in Figure 1. This characterization result was then identified by using JCPDS.

Diffractogram of the analysis result shows that the sample is dominated by $\mathrm{SiO}_{2}$ (quartz - JCPDS Card No: 046-1045) and $\mathrm{Al}_{2} \mathrm{O}_{3} .2 \mathrm{SiO}_{2} .2 \mathrm{H}_{2} \mathrm{O}$ (kaolinite - JCPDS Card No: $029-1488) .{ }^{15-16}$ If this diffractogram is compared to the analysis result using XRF, it is still incomplete. The detected elements by XRD are only the elements of $\mathrm{Al}$ and $\mathrm{Si}$, while the elements of $\mathrm{Fe}, \mathrm{Ca}$ and $\mathrm{Ti}$ are not detected. This is presumably because the compounds formed by those elements were still in amorphous phase.

FTIR gives information about organic and inorganic fractions of clays. Apart from detecting crystalline minerals, this characterization also identification pseudoamorphous components. ${ }^{17}$ The analysis result of FTIR in the sample of clay from Rendeng Village is present in Figure 2. 


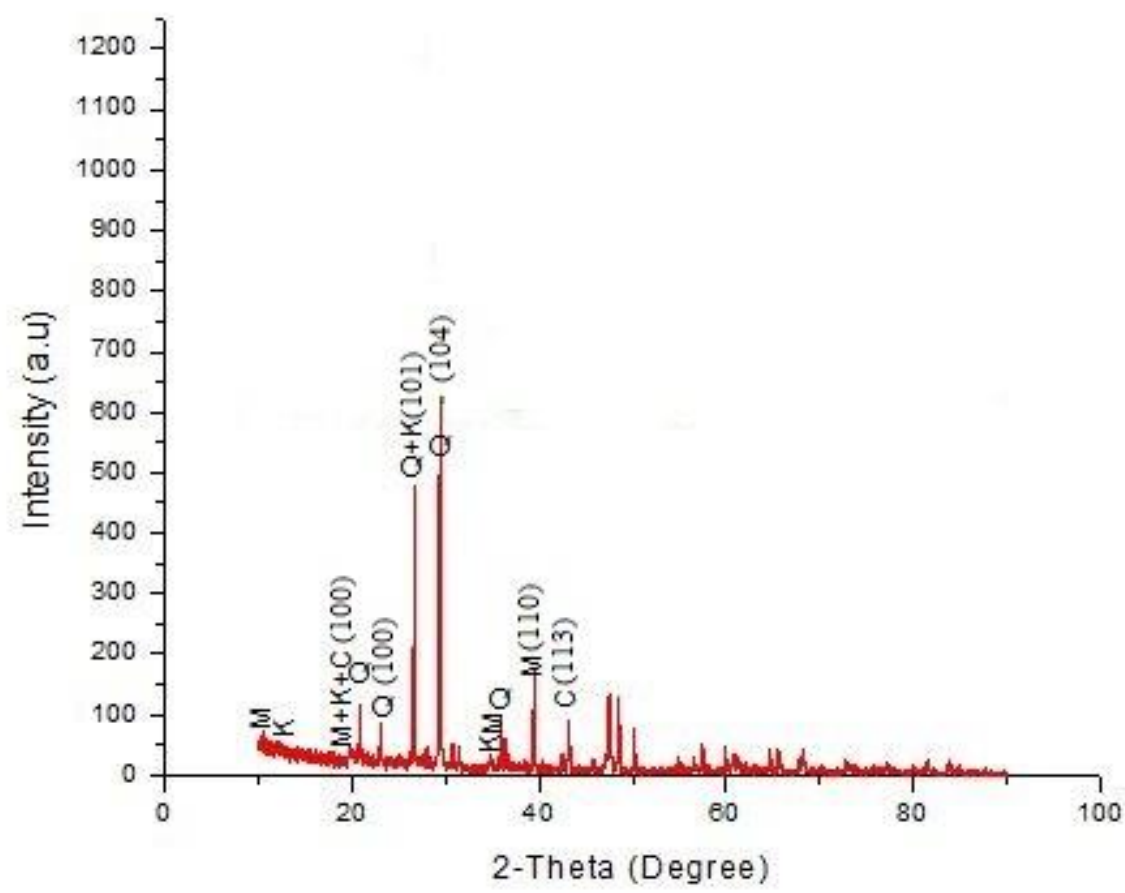

Figure 1. Diffractogram of Clay Sample

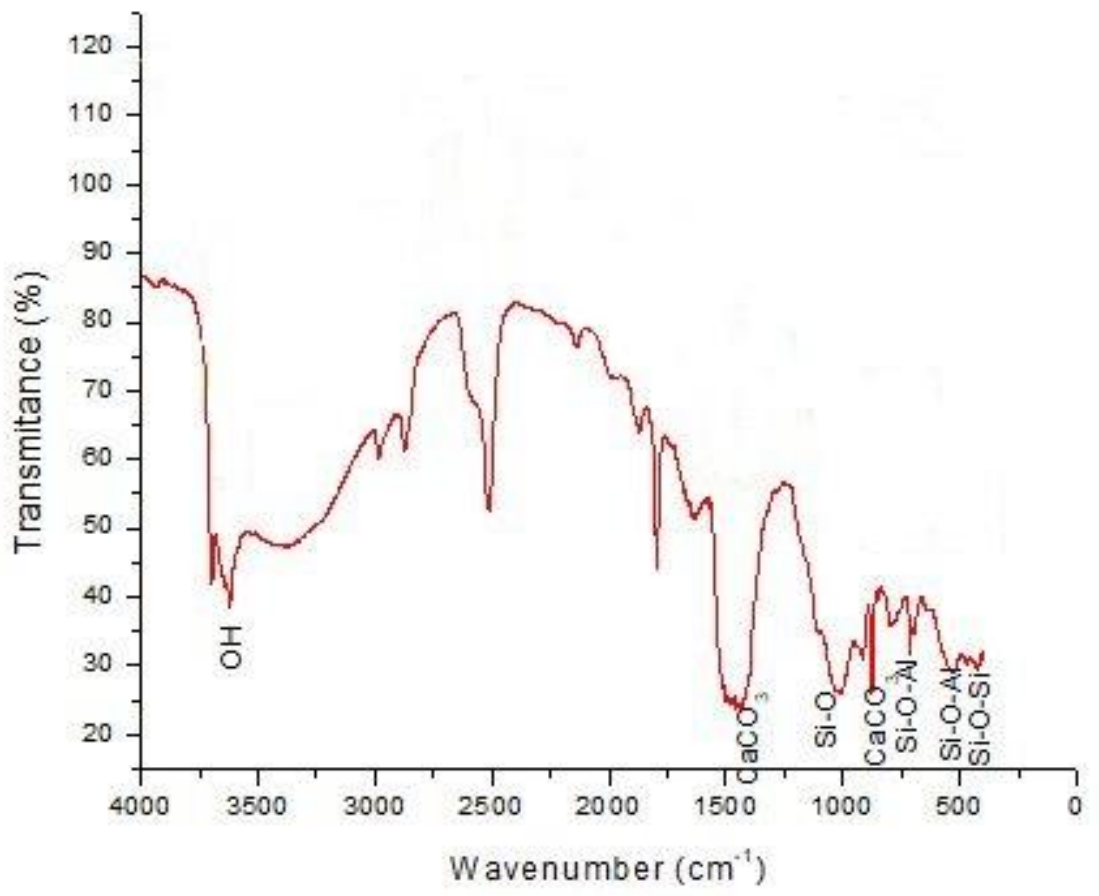

Figure 2. Analysis Result of FTIR of Clay Sample

The results obtained from FTIR analysis can correlate with the results obtained of XRF and XRD analysis. By giving a strong absorption result at a wave number between 900 and $1200 \mathrm{~cm}^{-1}$ and being centered on a wave number $1051 \mathrm{~cm}^{-1}$ in accordance with the $\mathrm{Si}-\mathrm{O}$ vibration stretching, ${ }^{14}$ the $\mathrm{Si}-\mathrm{O}-\mathrm{Al}$ bond is seen at a wavelength of about 798 $\mathrm{cm}^{-1}{ }^{14}$ The absorption of wavelength of 3600 $\mathrm{cm}^{-1}$ showed an elongation of internal vibration of the $\mathrm{OH}$ group. ${ }^{14}$

The physicochemical analysis carried out on the clay materials used in the Rendeng, Malo Pottery shows that it can use as pottery 
raw materials. But because of their content materials, they can't use them to make fine ceramics.

\section{Conclusion}

Clay at Rendeng Village, Malo contains the minerals of kaolin, quartz, and feldspar. This has been proven from the analysis result using XRF, XRD, and FTIR. Meanwhile, the physical properties of the utilization of clay were tested using the atterberg method with the result that the clay was less plastic.

The overall analysis result has showed that the clay from Rendang Village, Malo, Bojonegoro is only suitable to be used as a raw material for making pottery ceramics because the contained materials do not fulfill the requirements of the SNI quality.

\section{Acknowledgment}

Acknowledgments are funded by the Ministry of Research of Technology and Higher Education (RistekDikti) through the Institute of Research and Community Service Universitas Bojonegoro with scheme Penelitian Dosen Pemula (PDP) Grant contract number 8/ E1/ KPT/ 2020 and 083/ SP2H/ LT/ DRPM/ 2020; 029/ SP2H/ LTMONO/ LL7/ 2020; 037/ LPPM-LIT/ UB/ V/ 2020.

\section{References}

1. El Kasmi S, Zriouil M, Ahmamou M, Barka N. Physico-chemical and mineralogical characterization of clays collected from Akrach region in Morocco. J Mater Environ Sci. 2016;7(10):3767-74.

2. Gonggo ST, Edyanti F. Physicochemical Characterization Of Clay Minerals As A Raw Material Of Ceramic Industry In Desa Lembah Bomban Kec. Bolano Lambunu Kab. Parigi Moutong. Akad Kim. 2013;2(2):105-13.

3. Sultana MS, Zaman MN, Rahman MA, Biswas PK, Nandy PK. Mineralogical and Physical Characterization of Clay of Sitakunda Anticline: Used for Ceramic Industries. J Miner Mater Charact Eng.
2018;06(03):333-44.

4. Ribeiro MJ, Ferreira JM, Labrincha JA. Plastic behaviour of different ceramic pastes processed by extrusion. Ceram Int. 2005;31(4):515-9.

5. Winarno T. Perbandingan Karakteristik Lempung Kasongan dan Godean Sebagai Bahan Baku Industri Gerabah Kasongan. Teknik. 2016;37(1):41.

6. Perbup. 33 ttg penetapan kawasan pedesaan.pdf.

7. Agustinus ETS. Rekayasa Benefisiasi, Pemrosesan Mineral untuk Meningkatkan Nilai Tambah Sumber Daya Mineral Marginal [Internet]. Cetakan Pe. Aprianita TD, editor. Jakarta: LIPI Press; 2019. 148 p. Available from: https://lipipress.lipi.go.id/detailpost/reka yasa-benefisiasi-pemrosesan-mineraluntuk-meningkatkan-nilai-tambahsumber-daya-mineral-marginal

8. Ukiman. Karakteristik indeks plastisitas tanah terhadap tegangan geser dan regangan geser. Wahana Tek Sipil [Internet]. 2009;14(1):29-37. Available from:

https://ojs.petra.ac.id/ojsnew/index.php/ wahana/article/view/17768

9. Andrade FA, Al-qureshi HA, Hotza D. Applied Clay Science Measuring the plasticity of clays : A review. Appl Clay Sci [Internet]. 2011;51(1-2):1-7. Available from: http://dx.doi.org/10.1016/j.clay.2010.10. 028

10. Bernardin AM. Determination of Clay Plasticity. Appl Clay Sci. 2017;40(October):15-9.

11. Er-ramly A, Ider A. Physicochemical and Mineralogical Characterization of Moroccan Clay of Taza and Its Use in Ceramic Technology. Am J Nano Res Appl. 2016;4(2):17-22.

12. Papakosta V, Lopez-Costas O, Isaksson S. Multi-method (FTIR, XRD, PXRF) analysis of Ertebølle pottery ceramics from Scania, southern Sweden. Archaeometry. 2020;62(4):677-93.

13. Dewi R, Agusnar H, Alfian Z, Tamrin. 
Characterization of technical kaolin using XRF, SEM, XRD, FTIR and its potentials as industrial raw materials. $\mathrm{J}$ Phys Conf Ser. 2018;1116(4).

14. Halim M El, Daoudi L, Ouahabi M El, Amakrane J. Mineralogy and firing characteristics of clayey materials used for ceramic ! purposes from Sale region ( Morocco ). 2018;9(8):2263-73.

15. Çelik H. Technological Characterization and Comparison of Two Ceramic Clays Used for Manufacturing of Traditional Ceramic Products in TurkeyTürkiye' De GelenekselSeramikÜrünlerinİmalatinda Kullanilan. Mining. 2017;56(4):137-47.

16. Assila O, Tanji K, Zouheir M, Arrahli A, Nahali L, Zerrouq F, et al. Adsorption Studies on the Removal of Textile Effluent over Two Natural Eco-Friendly Adsorbents. 2020;2020.

17. Shoval S, Shoval S. Fourier Transform Infrared Spectroscopy (FT-IR) in Archaeological Ceramic Analysis. Oxford Handb Archaeol Ceram Anal. 2016;(April 2018):508-30. 